\title{
Lumen
}

Selected Proceedings from the Canadian Society for Eighteenth-Century Studies

\section{'Curious Scotch Plants': Scotland as the Exotic in the Early Edinburgh Physic Garden}

\section{Kathryn James}

Volume 24, 2005

Indigenes and Exoticism

Indigènes et exotisme

URI : https://id.erudit.org/iderudit/1012180ar

DOI : https://doi.org/10.7202/1012180ar

Aller au sommaire du numéro

Éditeur(s)

Canadian Society for Eighteenth-Century Studies / Société canadienne d'étude du dix-huitième siècle

ISSN

1209-3696 (imprimé)

1927-8284 (numérique)

Découvrir la revue

Citer cet article

James, K. (2005). 'Curious Scotch Plants': Scotland as the Exotic in the Early

Edinburgh Physic Garden. Lumen, 24, 135-148.

https://doi.org/10.7202/1012180ar

Copyright (C Canadian Society for Eighteenth-Century Studies / Sociéte canadienne d'étude du dix-huitième siècle, 2005
Ce document est protégé par la loi sur le droit d'auteur. L'utilisation des services d'Érudit (y compris la reproduction) est assujettie à sa politique d'utilisation que vous pouvez consulter en ligne.

https://apropos.erudit.org/fr/usagers/politique-dutilisation/ 


\section{0. 'Curious Scotch Plants': Scotland as the Exotic in the Early Edinburgh Physic Garden}

When William Nicolson, Archdeacon of Carlisle, sought to compliment the labors of the Keeper of the Edinburgh physic garden, he could without any difficulty praise the surprising breadth attained within a collection which had been established only circa 1670. Nicolson emphasizes the versatility of the garden's collection: 'the great Variety of Seeds and Plants, which [the Keeper's] Correspondents abroad have furnished him with, have mightily encreased his foreign Stock; and ... amply discovered to him the Riches of his own Country: So that we have sufficient Encouragement to hope that he will shortly oblige us with a new Prospect of one of the best furnished Gardens in Europe. ${ }^{\prime 1}$ The 'Riches of his own Country' - the collection and cultivation of plants native to Scotland - was a perennial theme in the garden's description. Scottishness was a quality which was cultivated in the Edinburgh physic garden from its earliest inception. The definition of Scottishness - its purpose, use, and manifestation - varied quite considerably, however, within the garden during its early years.

The early Edinburgh physic garden simultaneously exhibited and exoticized Scottish identity in several distinct ways. Complementary versions of 'Scottishness' were articulated by Robert Sibbald, the garden's co-founder, and James Sutherland, the first Keeper. Founded by Sibbald as a Hippocratic medical collection, the Edinburgh physic garden was intended as a showcase - both utilitarian and decorative - of those natural historical commodities unique to Scotland. On the one hand, then, the garden's key purpose was to present the botanical features of an innately Scottish landscape. On the other hand, under Sutherland's systematic management, Scottishness was also featured as only one identity within the garden's increasingly cosmopolitan collec-

1 W. Nicolson, The Scottish Historical Library (London: for T. Childe, 1702), 33. 
tion. Exotic Scottish plants were exchanged for plants equally exotic to Scotland. Scottishness, in the garden's practice, commanded a premium exchange value, but Scottish plants were treated as commodities within a botanical marketplace. What is more, the garden was also a training ground for Scottish medical apprentices. Many of these apprentices worked in the Indies trade, where they acted as collectors in the exchange and correspondence network surrounding exotic natural historical specimens. Thus, the Edinburgh physic garden, and with it the emerging discourses of botany and medicine, demonstrates the intersection of global commerce and native science - exoticism and indigeneity - in eighteenth century culture.

\section{Robert Sibbald's Garden: Native And Exotic Scotland}

It was specifically to house the products - curious and botanical - of the kingdom of Scotland that the Edinburgh physic garden was established c. 1670 by the two Scottish physicians, Robert Sibbald and Andrew Balfour. Sibbald - the more dedicated, or perhaps simply more loquacious of the two - founded the Edinburgh physic garden with the same optimistic vigour with which he promoted, unsuccessfully, the establishment of a Royal Society of Scotland. ${ }^{2}$ It was, as he describes, in his Memoirs, a plan he brought back with him from the cosmopolitan hubs

2 Sir Robert Sibbald (1641-1722) was an Edinburgh physician, antiquary, and natural historian. The author of several chorographies of Scotland, Sibbald was an active correspondent and promoter of civic activity in Edinburgh. Sibbald's enthusiasm for civic improvements is discernible in his autobiographical memoirs. See Robert Sibbald, The Memoirs of Sir Robert Sibbald (1641-1722), ed. F. P. Hett (London: Oxford University Press, 1932). On Sibbald's institutionalizing propensities, see Roger Emerson, 'Sir Robert Sibbald, Kt, the Royal Society of Scotland and the Origins of the Scottish Enlightenment' (Annals of Science 45 [1988]: 41-72) and, more summarily, W. S. Craig, History of the Royal College of Physicians of Edinburgh (Oxford: Blackwell Scientific Publications, 1976). Steven Shapin offers two earlier examinations in his 'The audience for science in eighteenth century Edinburgh' (History of Science 12 [1974]: 95-121), and his 'Property, patronage, and the politics of science: The founding of the Royal Society of Scotland' (British Journal for the History of Science 7 [1974]: 1-41). J. M. Cowan's two-part history of the early Edinburgh physic garden remains the most comprehensive survey of the garden's establishment: see J. M. Cowan, 'The history of the Royal Botanic Garden Edinburgh,' Notes from the Royal Botanic Garden Edinburgh, 1933-1938, 19: 1-62, 63-134. Less useful for the garden's early history is H. Fletcher and W. H. Brown, The Royal Botanic Garden Edinburgh, 1670-1970 (Edinburgh: H.M.S.O., 1970). 
of the Continent, where he received his medical education at Leiden, Amsterdam, and Paris. 'I had from my settlement here,' Sibbald writes,

a designe to informe myself of the subjects of the naturall history this country could affoord, for I had learned at Paris that the simplest method of Physick was the best, and these that the country affoorded came nearest to our temper, and agreed best with us, so I resolved to make it part of my studie to know what animalls, vegetables, mineralls, metalls, and substances cast up by the sea, were found in this country, yt might be of use in medicine, or other artes usefull to human lyfe, and I began to be curious in searching after ym and collecting ym, which I continued to do ever since. ${ }^{3}$

The Scottish natural history, as articulated by Sibbald, matches the commodities of the landscape - that which 'might be of use' - to the country's temper, the essential character of its inhabitants. Scottish specimens, in Sibbald's garden, become remarkable or collectible by virtue of their utility to the Scots themselves. ${ }^{4}$ An underpinning curiosity about Scotland itself can be discerned as well, however, fuelling Sibbald's drive to 'informe myself of the subjects of the natural history this country could affoord. ${ }^{5}$

A second, and as important, role for the garden emerged alongside this essentialist program. The Edinburgh physic garden was intended,

3 Sibbald, Memoirs, 64-65.

4 Lisbet Koerner argues for a similar conflation of regional landscape and character in her examination of the role of political economy in Linnaeus's view of nature as a 'single self-regulating mechanism, with each nation containing all the natural products necessary for a complete and complex economy' (Linnaeus: Nature and Nation [Cambridge, MA: Harvard University Press, 1999], 7).

5 Sibbald, Memoirs. Sibbald's curiosity about the Scottish natural history (natural history being a term which could and did encompass the cultural, historical, and genealogical landscape as well) seems to have fed both his botanical interests and his activities as a geographer and chorographer. For an overview of Sibbald's work as a geographer - Geographer Royal, from 1682 - see C. Withers, Geography, Science and National Identity: Scotland Since 1520 (Cambridge: Cambridge University Press, 2001), his 'Reporting, mapping, trusting: Making geographical knowledge in the late seventeenth century' (Isis 90 [1999]: 497-521), and his earlier 'Geography, Science and National Identity in Early Modern Britain: The Case of Scotland and the Work of Robert Sibbald (1641-1722)' (Annals of Science, 53 [1996]: 29-73). Especially interesting is Withers's discussion of Sibbald's queries, circulated to solicit chorographical information, as manifestations of one of the epistemological practices by which natural historical knowledge was constituted and accredited in the late seventeenth century. See Withers, Geography, 77-82. 
from the outset, as an ornament to the cosmopolitan fortunes of the city - and, by extension, the kingdom. The plants and books which underpinned this project came from the accumulated collections of Sibbald, Andrew Balfour, and James Murray from their European travels. ${ }^{6}$ The resulting correspondence between Balfour and Murray, on Murray's journey to France, 'gave the rise' — in Sibbald's words - 'to the designe of establishing the medicine garden at Edr. ${ }^{7}$ From the beginning, the garden was conceived as a cabinet, an ornament to the virtuosic fortunes of Edinburgh. The garden acted to display not only those beneficial botanicals innate to the Scottish landscape, but also the practices of the Edinburgh intellectuals themselves, participating in the cosmopolitan venture of natural historical correspondence and collecting.

Sibbald describes the foundation of the physic garden in his Memoirs, concentrating on the Hippocratic and decorative aspects of the garden's role as a repository for Scottish plants. In Sibbald's narrative, the garden sprang seamlessly from Balfour's and his initial plan into its first manifestation: the forty by forty foot plot by Holyrood House, kept by James Sutherland:

Doctor Balfour and I first resolved upon it, and obtained of John Brown, gardner of the North yardes in the Abbey, ane inclosure of some 40 foot of measure every way. We had, by this time, become acquaint with Master James Sutherland, a youth, who, by his own industry, had attained great knowledge of the plants and of medals, and he undertook the charge of the culture of it. By what we procured from Leviston and other gardens, and brought in from the Country, we made a collection of eight or nyne hundred plants $\mathrm{yr}^{8}$.

It was as a project for the benefit of Scotland — both as an economy and as a society - that Sibbald proposed the physic garden. Scotland was to be studied, its subjects catalogued and collected. The work was to be a utilitarian one, enabling the better exploitation of Scotland's resources on the political, economic, and domestic stage. It was also, however, a

6 Murray was a prolific botanical collector and correspondent, accumulating, in Sibbald's description, 'of plants that grew in the country and foreigne ones neer to a thousand' (Memoirs, 65). Andrew Balfour (1630-1694) was an acquaintance of Sibbald's from his time in France. Like Sibbald, Balfour was a Scot who received his M.D. in Caen after a period of study abroad, returning to Scotland and, eventually, Edinburgh to practice. See Fletcher and Brown, 3-5.

7 Sibbald, Memoirs, 65.

8 Sibbald, Memoirs, 65-66. 
moral exercise, one involving the recognition of those talents, as it were, which Scotland might have hidden under its bushels. Sibbald's curiosity, in 'searching after' and collecting the products of the kingdom, was intended to lead both to medical and economic utility and to the perfection of those 'other artes usefull to human lyfe.' In a letter to Hans Sloane of 12 June 1701, Sibbald summarized the philosophy with which he had approached his chorographies of Scotland: 'My care hath been most to find out what this Country produceth, and I continue this my search: wherin I may serve you as to what is found here, you may command me. $^{\prime 9}$

It is as a burgeoning collection that the garden comes most clearly into focus in its early years. Sibbald describes, with enthusiasm, the energies which were funneled into the seemingly indiscriminate collection of plants both domestic and foreign. The garden, in Sibbald's brief description, serves as the object of 'embellishing, 'importing,' and 'procuring,' acting as a vessel for the collecting enthusiasms of Sibbald, Sutherland, and Balfour:

After this, we applied ourselves with much care to embellish the fabrick of the garden, and import plants from all places into this garden, ... and by Dr Balfour's procurement, considerable pacquets of seeds and plants were yeerly sent hither from abroad, and students of medicine got directions to send ym from all places they traveled to, wher they might be had, by which means the garden increased considerably every yeer. ${ }^{10}$

Sibbald stresses the importance to Scotland of his researches. The 'products of the kingdom' are to be searched out, catalogued, and exhibited as the Hippocratic landmarks of an essentially Scottish landscape. It is the domestic landscape which, to Sibbald, constitutes the 'exotic.' It is as a public wealth of curiosities - both useful and delightful - that Sibbald presents Scotland, displayed in the cabinet of the physic garden.

9 Robert Sibbald to Hans Sloane, 12 June 1701, Edinburgh University Library Manuscripts (hereafter EUL MSS), DC.8.35: 19-20. Sir Hans Sloane (1660-1753) was a British physician and naturalist whose lifelong collections and correspondence formed the basis of the British Museum. See Dictionary of National Biography, 'Sir Hans Sloane.' For an overview of Sloane's activities as a collector, see A. MacGregor, ed., Sir Hans Sloane: Collector, Scientist, Antiquary (London: British Museum Press, 1994).

10 Sibbald, Memoirs, 66-67. 


\section{James Sutherland's Garden: Scotica As Export}

Sibbald was pivotal both in the physic garden's founding and in the diplomatic negotiations surrounding the garden's early development. The garden itself, however, grew under the care and correspondence of James Sutherland. The garden contained both plants native to Scotland and foreign plants, imported as seeds or 'setts' through correspondence. Sibbald describes the garden as containing

not only quite a number of plants indigenous to this country, but also plants from both hemispheres, especially those which have been distributed through all countries, for the cure of sickness and disease; here almost all of these have been gathered together and grow quite well. The total number of all the plants is approximately two thousand, of which, the worthy keepr of the Garden, James Sutherland, Master of Arts and student of medicine, will shortly issue a catalogue. ${ }^{11}$

Sutherland's activity was pivotal to the garden's initial success. It was Sutherland, rather than Sibbald, who acted as the 'worthy keeper,' compiling and cataloguing the plants.

The Edinburgh physic garden was quick to develop as a collection of Scottish and imported plants. In 1683, James Sutherland first published a catalogue of the garden's holdings, his Hortus medicus Edinburgensis.

11 Cowan, 18. Walker emphasizes the role, as well, of Balfour's correspondence in enriching the garden's stocks, noting his correspondence with 'Morison at Oxford, Marchant at Paris, Hermann at Leyden, Watts at London, and Spotswood at Tangiers.' See J. Walker, 'Memoirs of Sir Andrew Balfour,' in his Essays on Natural History and Rural Economy (Edinburgh: Edinburgh University Press, 1808), 358-59. A. Stroup, in her A Company of Scientists: Botany, Patronage, and Community at the seventeenth-century Parisian Royal Academy of Scientists (Berkeley, University of California Press, 1990), articulates the importance of Anglo-French botanical exchanges and natural historical correspondence but does not discuss the Scottish influence. On the subject of James Sutherland, there is less early biographical information than one could wish. What there is stems primarily from Robert Sibbald's account in his autobiography, the Edinburgh Town Council records, the Sloane correspondence, and Sutherland's Hortus medicus Edinburgensis (Edinburgh: by the heir of Andrew Anderson to be sold by Henry Ferguson and at the physic garden by the author, 1683). Blanche Henrey's account remains the most succinct: 'Sutherland was an expert gardener, a learned botanist, an accomplished Latin scholar, and a good man of business, and under his care the garden thrived and became famous throughout Europe' (British Botanical and Horticultural Literature before 1800, 2 vols. [London: Oxford University Press, 1975], 1: 153). 
Sutherland's work details some 1952 plants, marked in annotations as medicinal, Scottish, and/or annual. Sutherland describes his motives in publishing the catalogue, premising

that I might thereby let the World know what Plants I could furnish to others, who are curious in this so useful a part of natural Philosophie, and what I could not; that so all who apply themselves to promote Natural History with me, might be encouraged to assist me in so good a designe, by making interchange of Plants, which they can spare and I want, with others They want and I can spare. ${ }^{12}$

The catalogue did not present the garden as an archive, or finite repository, but acted as something more along the lines of an auction catalogue. It was as a collection - a repository of choice desirables or a potential source for other collectors - that the Edinburgh physic garden was of interest to Sutherland's correspondents and audience for the Hortus medicus Edinburgensis. Like Sutherland's own collection of Roman coins, like Hans Sloane's collection of natural historical curiosities, the garden's appeal lay less in its status as a static monument than in its potential to act as marketplace in the exchange of botanical currency.

Sutherland's writing reinforces a sense of the invisibility - once collected and catalogued, once identified as a gap to be filled or to fill another collection - of the plants themselves in the physic garden. Plants appear in lists in his correspondence, as specimens to tempt collectors, or as gaps needing to be filled in his own collection. 'Pray be pleased to let me know if ye desire Specimens of any of our country plants,' he writes, in a letter of 1700, reeling off a catalogue of possibilities: 'Pyrola Alsines flore [chickweed wintergreen], Chamaepericlymenum [bunchberry], Chamaemorus [knot berry or cloud berry], Sedum minus ericoides [purple saxifrage], Rosmarinum silvestre nostras [wild rosemary], Orobus Sylvaticus nostras [wood vetch], and the like that may be rare with you. ${ }^{13}$ Even Scottish

12 Sutherland, Hortus medicus Edinburgensis, preface. Sutherland also gives an index of English names in this work.

13 James Sutherland to James Petiver, 25 March 1700, British Library Sloane Manuscripts (hereafter Sloane MSS), 4063: 9. The correspondence surrounding the early Edinburgh garden is reprinted in Cowan, 'The History of the Royal Botanic Garden Edinburgh' (n. 2). Brackets here enclose the contemporary common names. Cowan very usefully provides Linnaean translations of pre-Linnaean nomenclature: Trientalis europaea $\mathrm{L}$. (Pyrola Alsines flora); Cornus suecica L. (Chamaepericlymenum); Rubus Chamaemorus 
specimens, denoted in the catalogue by an 'S.' in the margin, are not otherwise elaborated. ${ }^{14}$

Once filed into their organizing framework, the plants acquire interest primarily as possible acquisitions, as specimens available in the catalogue. In the dedication of the Hortus medicus Edinburgensis to George Drummond, he asserts that he 'shall not here trouble you with an tedious Account of the Garden itself.' It is as a catalogue, represented in the Hortus medicus Edinburgensis, that the garden's use and worth appear: 'it will sufficiently appear to your Lordship, and to all the World, by this Catalogue how well it is instructed; and I dare boldly say, comparing it with the Catalogues of other Gardens abroad, it runs up with most of them, either for Number, or Rarity of Plants. ${ }^{15}$ Sutherland describes his labours towards gathering the landscape of Scotland into the garden, to place alongside the products of the rest of the world. He elaborates upon his own pains, in accumulating plant specimens on travels around Scotland, and emphasizes the magnitude of the correspondence he maintains with plant collectors around the world. 'It having been my Bussiness these seven years past,' he states

wherein I have had the Honour to serve the City as Intendant over the Garden, to use all Care and Industry by forraign Correspondence to Acquire both Seeds and Plants from the Levant, Italy, Spain, France, Holland, England, east and west Indies; and by many painful Journeys in all the Seasons of the year, to recover whatever the Kingdom produceth of Variety, and to cultivate and preserve all of them with all possible Diligence. ${ }^{16}$

L. (Chamaemorus); Saxifraga oppositifolia L. (Sedum minus ericoides); Andromeda polifolia L. (Rosmarinum silvestre nostras); Vicia Orobosu DC (Orobus Sylvaticus nostras). See Cowan, 'The History of the Royal Botanic Garden Edinburgh,' 37.

14 Several specimens of heather are listed, for example, with an 'S.' to designate their particularly Scottish quality. The plants are catalogued with their matching Latin and common names from botanical sources such as Caspar Bauhin's Pinax [B.P.], John Gerard's Herbal [Ger.], and John Parkinson's Theatrum botanicum [Park.], e.g. 'Erica baccifera procumbens nigra B.P. baccifera procumbens Ger: baccifera Matthioli $I B$. baccifera nigra Park: Berry-bearing Heath,' 'Erica vulgaris Ger: Park: vulgaris glabra B.P. vulgaris humilis semper virens flore purpureo \& albo I.B. Common Heath. Offic.' See Sutherland, Hortus medicus Edinburgensis, 109-110.

15 Sutherland, Hortus medicus Edinburgensis, dedication.

16 Sutherland, Hortus medicus Edinburgensis. 
The successful garden, rather than simply reflecting Scotland, acts as a mirror of the world. ${ }^{17}$ The glory which the Edinburgh physic garden has attained lies in its comprehensiveness - the ability of Edinburgh to compete with the cities of Italy, France, Holland, and England in compiling a complete selection of botanical specimens.

Scotland, however, served an extremely important purpose in Sutherland's curatorship of the garden's collection. It was through his ability to provide Scottish plants, 'Scotica,' that Sutherland could encourage trade. The garden's remote aspect - remote, that is, from England and the Continent - lent it the cachet of the exotic. It is not surprising, therefore, to find that Sutherland was an active proponent and collector of indigent or native Scottish specimens. He writes, in 1700, to declare:

I intend (God willing) to travell all Scotland over that I may make a full collection of all the plantes Indigence ... I did begin last Summer and travelled afoot upwards of two hundred miles with great ease and satisfaction and so I purpose to continue every year till I search the whole Kingdom, and ye may be sure, I will not confine myself only to plants but will likewise notice and inquire after all other Naturall Curiosities. ${ }^{18}$

It is with this vigorous announcement of intent that Sutherland introduces himself, from Edinburgh in 1700, to James Petiver, the London apothecary, natural historian, and Fellow of the Royal Society. ${ }^{19}$ The letter marks the beginning of a robust trafficking in those services, exchanges, news, bearers, and acquaintanceships by which natural his-

17 The successful garden could also act as a mirror of Britain. Sutherland actively adopted John Ray's broader project of assembling a complete British flora, a goal which Ray pursued in his Snyposis stirpium Britannicarum (London: Sam. Smith, 1690). Sutherland wished to replicate and exhibit this collection in the Edinburgh garden. He writes to Petiver, for instance, to enthuse that 'there is nothing I so much desire for our Physick Garden here at Edinburgh as a full collection of all the Plantes Indigence of Britain, which I'me planting in order after Mr. Rayes Method in his Methodica Stirpium Britannicarum' (James Sutherland to James Petiver, 17 September 1700, Sloane MSS, 4063: 43). On Ray, see C.E. Raven, John Ray, Naturalist, His Life and Works (Cambridge: Cambridge University Press, 1942).

18 Sutherland to Petiver, 25 March 1700.

19 An avid correspondent and natural historian, James Petiver (1663/4-1718) was a London apothecary, natural historian, and Fellow of the Royal Society whose collections were purchased by Hans Sloane upon his death in 1718. See R. P. Stearns, James Petiver: Promoter of Natural Science (Worcester, MA: American Antiquarian Society, 1953). 
tory was conducted in the late seventeenth-century. 'And if the Kingdom of Scotland produces anything worth your while,' promises Sutherland, 'I myself shall be at pains to procure it for you. ${ }^{20}$

Sutherland formed the garden's collections through his own 'herbarizing' expeditions throughout Scotland. He describes these excursions as a means by which to supply Petiver with native Scottish specimens - 'exotics,' in London. In a letter of 24 June 1700, Sutherland states that he 'intends towards the end of the next month to begin my herbarizing through the Highlands of Perthshire where I shall meet with ... many curious mountainous Scots plants being very earnest about collecting Plantes Indigence of Britain. ${ }^{21}$ Again, in a letter of 29 January 1701, Sutherland promises to 'this Summer take all possible pains to collect for you a sufficient number of dryed Specimens of all the Curious Scotch Plants I can meet with, as ye desire. ${ }^{22}$

It is in terms of his capacity to collect, to receive Scotch specimens from Scottish correspondents and to transmit 'Curious Scotch Plants,' that Sutherland presents his employment as 'Intendant' of the physic garden. ${ }^{23}$ Maintaining acquaintances and correspondence is as important if not more so - as collecting specimens, caring for the garden, or using it as a medical educational establishment. Sutherland accumulated lists from his acquaintances, and either met them himself or, as shown in a letter of 22 August 1701, delegated the task to a friend: 'Mr Archibald Stewart is gone to the Highlands to passe his time till the beginning of November, he Knows the Plants of that place exactly well and I have Given him both Doctor Sherards List and yours that he may gather Sets

20 Sutherland to Petiver, 25 March 1700.

21 Sutherland to Petiver, Edinburgh 24 Jany 1700, Sloane MSS, 4063: 32. Internal evidence would indicate that this letter was actually dated 24 June 1700 . Sutherland lists the specimens which he anticipates encountering on this venture: Camaepericlymenum [Cornus suecica L.], Pyrola Europaea Alsines flore [Trientalis europaea L.], Salix pumila montana folio rotundo J.B. [Salix herbacea L.], Thalictrum minimum montanum atrorubens foliis splendentibus [Thalictrum alpinum L.], Sedum minus Alpinum luteum nostras [Saxigraga aizoides L.], and Pentaphylloides pumila foliis ternis ad estremitates Perfides [Potentilla]. See Cowan, 42.

22 Sutherland to Petiver, Edinburgh 20 January 1701, Sloane MSS, 4063: 101.

23 H. M. Endersby offers an analysis of the mechanisms by which the value - whether in terms of remuneration or the more subjective rewards of patronage, publicity, or reciprocal exchange - of specimens was assessed through natural historical exchange in his study of the Australian botanical garden, 'A Garden Enclosed: Botanical Barter in Sydney, 1818-39,' British Journal for the History of Science 33 (2001): 313-34. 
and specimens of all thats curious there. ${ }^{24}$ It is the 'curious,' rather than the strictly medicinal, which Sutherland emphasizes in his correspondence concerning the garden with Petiver. Scottishness was at a premium, in Sutherland's management of the garden, when it could be exchanged for exotics from abroad.

\section{The Medical Garden: The Scottish Apprentices As Export}

Plants, however, were not the garden's only export. As the town records surrounding the garden's early history indicate, the Edinburgh physic garden found fiscal justification both as an ornament to Edinburgh and, perhaps more importantly, as the training ground for medical apprentices. The garden was an important educational site for the professional training of the Edinburgh surgeon and apothecary apprentices. The apprentices were required to present themselves at five o'clock in the morning, in the summer, to be taught the materia medica, or names and properties of medicinal herbs. A portion of the garden was organized, like a museum exhibit, so that the apprentices could read the plants from their categorization in the garden beds. The garden was not just a catalogue. It also acted as a text, a living reference work on the materia medica to be consulted by the medical apprentices.

The Edinburgh physic garden's success as a teaching facility for medical apprentices is lauded - and rewarded - in the Town Council records. On 15 July 1693, Sutherland is found petitioning the Council for repairs to the gardener's house, in which he describes his 'constant attendence at ye garden,'

indispensablie requisite ye most part of the year [particularly] in the winter and Spring for defending and takeing caire of the more tender and foreigne plants and in the sumer for waiting upon his Schollars who are oblidged to come to the garden at four or fyve a'clock in the morning that they might be tymously back to open and attend on ther masters shops As Likwayes the petitioner had now brought yt garden to a considerable pitch in so far yt for numbers and rareness of plants it is inferior to few gardens in Europe which he had for the most part done upon his owne charge and expense. ${ }^{25}$ 
These same medical apprentices, the 'Schollars,' also pervade Sutherland's correspondence with Petiver. Sutherland refers, in his letters to Petiver, to an extensive exchange network of plants, coins, books, and acquaintanceships. The letters chart a flow of specimens, the material commodities of the 'Naturall History.' Sutherland's scholars - the surgeon-apprentices whom he introduces to Petiver - are made visible as collectors, facilitators of the accumulation of natural historical objects. In a letter of 24 June 1700, Sutherland begins with the assertion that 'I shall always when any of my Schollars design to go to Sea Surgeons, abroad from London recommend them to your advice, that ye may give them your Instructions how to collect in their travels such things as may be serviceable to you. ${ }^{26}$

Lists accompany these apprentices, guiding them in their activities as agents of collection. Sutherland inevitably offers a hopeful request for specimens available in the South, offering in exchange the findings of his apprentices, the surplus of the garden, or the fruits of his own 'herbarizings' around Scotland in the summer. The result is a network of exchange and acquaintance, as in a passage from the same letter:

I want severall Grasses and other plants that may perhaps be found near London and have therefore sent a List of them to Mr. William Watt Chirurgeon lately come from Maryland, I have ordered him to wait on you, and let you see it, that ye may help me to seeds or sets of such of them as ye can procure which I assure will be very oblidgeing. ${ }^{27}$

A month previously, in a letter of 8 May 1700, Sutherland had made a similar recommendation and request: this time on behalf of Robert Moor, surgeon apothecary's apprentice. In Moor's case, Sutherland sought employment for him as a surgeon's mate, on a trade ship to the East or West Indies. Like Penman, however, he was recommended to Petiver on the strength of his potential as a collector. 'He may be capable,' Sutherland writes, 'to do you Service in collecting for your Museum as ye shall please to give him Instructions ... and I Know ye are very ready to encourage any that are so inclined. ${ }^{28}$ Again, on 15 May 1700, we find Sutherland offering the services of another potential collector, one William Cuninghame. Though 'he be not skilled with plants,' Cuninghame

26 Sutherland to Petiver, Edinburgh 24 Jany 1700, Sloane MSS, 4063: 32.

27 Ibid.

28 Sutherland to Petiver, Edinburgh 8 May 1700, Sloane MSS, 4063: 23. 
is presented as having promised 'to collect such naturall Curiosities as may come in his way, both for your use and mine' and 'may be diligent in gathering shels, Insects and such like. ${ }^{29}$ The Edinburgh physic garden acted as an important training ground for medical apprentices bound for the Indies trade. These Scottish apprentices, as much an export of the garden as the Scottish plants, contributed as collectors to a broader network of natural historical exchange and correspondence.

\section{Conclusion}

Scottishness was a commodity with a market value in the arena of early modern British natural history. While the garden was established as the showcase for Sibbald's Hippocratic 'products of the Kingdom,' the botanical manifestations of an innately Scottish landscape, the physic garden thrived as a cosmopolitan collection, as replete with foreign exotica as its counterparts in Britain and the Continent. The early success of the Edinburgh physic garden, under the care of James Sutherland, stemmed from Sutherland's ability to trade on Scotland's perceived remoteness from the gardens of the south of England and the Continent, its cachet as a source of foreign and exotic specimens. Because of Scotland's value as the source of exotica, Sutherland was able to build up an extensive collection of exotics from the equally remote gardens of England and the Continent.

The complexities of Sutherland's practice as a collector, natural historian, and the garden's Keeper are reflected in that repository of natural-historical knowledge: the Edinburgh physic garden. It was neither strictly an institution for medical education nor simply a decorative cabinet of botanical curiosities. The Scottish plants - reflections of that Hippocratic landscape whose cultivation, in founding the physic garden, Sibbald sought to promote - were exhibited, through Sutherland's correspondence and the Hortus medicus Edinburgensis, to a cosmopolitan audience for exchange. The Scottish medical apprentices, whose education in the materia medica constituted one of the primary justifications for the garden in the eyes of the Town Council, were directed abroad as botanical collectors in the Indies trade. The garden acted simultaneously as an exhibit of cosmopolitan quality - a civic ornament - and as a collection of Scottish plants, laboriously gathered 
148 Kathryn James

through 'herbarizing' expeditions, exchange, and correspondence. The Edinburgh physic garden acted as a marketplace for all things Scottish: both the 'Curious Scotch Plants,' exotics on the international exchange, and the equally curious Scots apprentices, trained in the arts of natural historical collecting.

KATHRYN JAMES 